was the intention to establish a camp, and leave behind a section of the party and of the escort. Col. Prjevalsky, with his companions, will push forward to the sources of the Yellow River, and even to the towns of Chambo and Batanou. If the circumstances are propitious, the expedition will devote the spring and summer of 1884 to the exploration of the region of Sifanei, between Koko-Nor and Batanou, where it will surely find abundant natural riches to explore. In autumn the expedition will return to its encampment. A part of the baggage will be sent to Gast, in Tsaidam, where they will establish a second camp. From Gast the expedition will traverse Northern Thibet in the direction of Lhassa, and will try to penetrate as far as the Lake Tenegri-Pora, to reach afterwards, if circumstances permit, either the province of Dsang, or to the Brahmaputra. If not successful, however, the expedition will return part of the way and then go northwards to Ladak and to Lake Daigro-Jum-Tcho. From thence it will return to Gast, and try afterwards to go across the plateau of Thibet in another direction. From Gast, which they expect to reach in the spring of 1885 , a part of the expedition will go towards Lob-Nor, and the other part towards Keria, that they also may reach Lob-Nor by way of Tcherkin. The two sections of the expedition will afterwards go together to Karakorum, and along the Khoton, and then return by Alsa to Asiatic Russia, near the Lake Issak-kul. Col. Prjevalsky left St. Petersburg on August 3, 1883, accompanied by Sub-Lieutenant Roborovsky, his assistant, and a volunteer, Kozloff. At Ourga they were joined by twenty soldiers for an escort, and on November 8 they left Ourga to cross the Desert of Gobi. The telegram just received from Alashan (dated January 20 ) tells of the safe arrival there of the expedition.

GEOGRAPIERS will be glad to find in the last volume of the Izrestia of the Caucasus Geographical Society a number of astronomical determinations of positions of places in the Transcaspian region, by $M$. Gladysheff. We find in the list a number of points in the oases of A khal-tekke and Merv, and in Khorassan, and notice that the exact position of Sarakhs (western corner of the citadel) is $36^{\circ} 32^{\prime} 14^{\prime \prime} \cdot 5 \mathrm{~N}$. lat. and $61^{\circ} \mathbf{1 0}^{\prime} \mathrm{IO}^{\prime \prime} \mathrm{E}$. long., 860 feet above the sea ; that of Merv (garden at Kaushut-khan-kala) $37^{\circ} 35^{\prime} 18^{\prime \prime} \cdot 3 \mathrm{~N}$. lat. and $60^{\circ} 47^{\prime} 16^{\prime \prime} \mathrm{E}$. long., 900 feet above the sea; and that of Meshed (cupola of Imam Riza) $36^{\circ} 17^{\prime} 25^{\prime \prime} \cdot 6$ $\mathrm{N}$. lat. and $59^{\circ} 37^{\prime} 27^{\prime \prime} \mathrm{E}$. long. The same volume contains a great number of heights measured in Asia Minor by Russian officers.

THE last issue of the Irvestia of the Russian Geographical Society contains a preliminary report of a journey made by MM. Adrianoff and Klementz in the still little-known islands to the south-west of Minusinsk; a note by MM. Hedroitz and Lessar, being a reply to M. Konshin's paper on the Kara-kum sands and the former bed of the Amu; a note, by M. Malakhoff on the remains of prehistoric man on the Nyeman, close by Druskeniki; the necrology of Admiral Putyatin, by Baron Osten-Sacken; and a note by M. Piltchikoff, on a magnetic anomaly between Kursk and Kharkoff.

\section{ON THE PROGRESS OF GEOLOG $Y^{1}$}

$\mathrm{IN}$ addressing you to-night at the opening of the session 1883 of Canterbury College, may I be allowed to appeal first to your kind indulgence? On an occasion like this you have a right to expect that only the best and most refined English should reach y our ear; and if this to-n'ght is not the case, you will, I truit, be lenient with me, as only very few foreigners have ever been able to master the beautiful and expressive English language so thoroughly that they would not now and then offend the ear of an educated audience.

When I look round me in this fine hall, and see before me such a large audience, of which a number consists of graduates of Canterbury College, it appears almost like a dream and not a reality - a reality of which we have every reason to be proud.

It is about sixteen years ago that a few earnest men, havi:ng the intellectual advancement of Canterbury at heart, met and proposed to found a university in Christchurch; but they were told by a not inconsiderable number of our citizens, some in hiy posi ions, that we were a hout a hundred years in advance of the wants of the colony. However, we persevered, and at

${ }^{1}$ An opening address delivered to the students of Canterbury College on March 28, 1883 , by Julius von Haast, Ph. D., F.R.S., Professor of Geology and Palæontology in Canterbury College (N.Z. Uriversity). last succeeded; and the best proof of the correctness of our views is the number of the graduates of the New Zealand University, of whom there are now twenty-one Masters of Arts and forty-nine Bachelors of Arts, together seventy ; of whom Canterbury College can claim twenty-nine of its own, many of whom would be an ornament to any university of the home country.

And although the greater portion of our graduates mostly apply the linowledge gained to the education of others, they continue their studies for their further intellectual progress long after they have gained their well-earned degrees.

To my mind no more ennobling or higher sphere can te selected by anybody than that of the teacher. What mental energy, what moral devotion are required in the teacher, who can only be successful if he has his whole heart in the work, so that the chain of human sympathy, the most powerful tie in mankind, unites him with his papil. In a young country, where wealth is generally concitered to give power, position, and influence, and the "auri sacra fames" is much developed, only a refined mind can gladly and willingly turn away from those pursuits by which wealth is more easily obtained, in order to devote bimself entirely to the education of the young.

Moreover, nothing shows us more clearly than teaching that we have only put our foot on the first step of the ladder leading to knowledge. We remain students our whole life; and I trust that none of our graduates will tver overrate the step gained, but that they will consider that the degree obtained has only given them an insight into the dominion of Knowledge, and has shown them how much they have still to learn; and that in fact they have become masters of the art how to learn to the advan. tage of themselves as well as of others.

Before entering into the subject I have chosen for to-night's address, I wish to make only a few remarks upon the development the Univer:ity of New Zealand ought to take, so as to satisfy the present and future wants of our population. It was only to be expected that in the beginning its founders should have been guided by the curriculum of the great centres of learning in Great Britain, although even then some of the newer inprovements were not adop:ed; but I may point out that under the different circumstances in which we live in a colony, we ought to have more cosmopolitan views, and profit by the experience of those States and e.munities which our conditions resemble most. In fact, the Universily of New Zealand ought to be tclectic, and to select for assimulation in its constitution the best as to manner and matter of teaching from all parts of the world.

According to my views it ought not to be at present the highest aim of a university course to offer a mass of knowledge of a chaotic character in a number of subjects, but to make the student acquainted with the general principles of the stock of knowled re possessed by the world and its application to life ; to know in what direction that gen ral stock is most deficient, and in what manner it can be augmented and made more useful both intellectu. Ily and practically.

The study of philosophy, in the highest and most general acceptance of the term, is one of the greatest wants for any univers:ty that intends to educate thinkers, men and women who not only wish to use their acquired knowledge for earning their daily bread, but to advance the human understanding.

Advancing to the subject upon which I wish to address you to-night, I have thought that some remarks on the progress geology ha; made and is daily making would not be inappropriate. I should also like to show, though owirg to the short time assigned to me this can only be done in a fragmentary manner, how from an empirical science it has gradually been raised to be an inductive science fully deserving, as far as actual observations go, to claim the p.sitio. of an exact ssience.

If we consult " The Cyclopædia, or an Universal Dictionary of Arts and Sciences," by E. Chambers, F.R.S., I.ondon, four large $f$, lio volumes, of which the first appeared in 1779 and the fourth in 1783 , an excellent work, for which s me of the most eminent men of the last century wrote, we find that the word geology, or geognisy, did not exist at that time, the principal information upon the formation and constitution of our earth being contained in the articles on basaltes, earth, fossils, geography, lithology, marine remains, mineralogy, mou.utain, rocks, stone, and volcano.

The explanation of the furmation of "stones" is in many

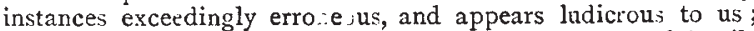
$\mathrm{u}$ hilst the explanation of the nature and occurrence of fossils is given quite correctly, al:hough the theory of Tournefort, pro- 
posed in 1702 to the Royal Academy of France, that all stones, fossils included, were derived from liquid stone seeds, is gravely considered and rejected.

The description of volcanoes, both active and extinct, is also given in a lucid manner; but the opinions as to the cause of vulcanicity are sometimes very peculiar, including the theory of Dr. Lister-that they are originated by an inflammable mineral called pyrites.

The origin of basalt (basaltes) is correctly given, according to the researches of Desmarest in Auvergne, and Raspe in Germany, so that before Werner no erroneous views on that subject were held.

But it is a most remarkable fact that there was not even an attempt made to give an explanation of stratigraphical geology, and how the different rocks were formed, or to conuect certain sets of fossils with certain rocks in which they occur; so that in many respects we can claim that geology is a child of the last hundred years.

Abraham Gottlob Werner, the great teacher of the Freiberg Academy of Mining, may be considered one of the founders of modern geology. In 1785 he delivered the first course of geognosy, as distinct from mineralogy, and by his great knowledge of all matters connected with the latter science and mining, and his excellent method of teaching, he had an enormous influence upon the advancement of geology. Therefore, as far as I am aware, the word ge gnnosy was first used two years after the last volume of Chambers" "Cyclopxdia" appeared.

A great retrograde step.was, however, made by Werner when be brought out his famous theory of the aqueous origin of basalt, ustally named the theory of Neptunism. After the war between the Neptunists and the Plutonists (those who maintained the igneous origin of basalt) had been raging for some years, most of the disciples of Werner-acting as partisans, and instead of trying to elucidate the truth, were only bent upon making by all means in their power the cause advocated by them victoriousfor a time managed to get the upper hand. Those scientific men, who knew from their own experience that Werner's doctrines on the subject were incorrect, preferred to retire from the contest, and refused to fight with the same unfair weapons.

Of equal, if not of greater importance, are the labours of James Hutton, who, in 1788 , published his "Theory of the Earth," in which, for the first time, the complicated structure of the surface of the earth is explained by the agency of natural forces, still at work at the present day. With this the foundation of modern geolozy was securely established, and though in some respects the great Scotch philosopher went too far, his system was, nevertheless, the only true one on which his successors could build that branch of knowledge now claiming a prominent rank amongst its sisters as an inductive science. And when William Smith, the modest English land surveyor, in 1790 published his "Tabular View of the British Strata," in which the first attempt was made to connect certain fossils with certain strata, an attempt turning out a masterpiece of palient research and skill, a further great step was made in advance, and instead of merely theori:ing on disconnected facts, the greater portion of geological students began to rely more upon the facts collected by them and others, than upon speculative views, however fascinating they might be.

In entering upon a short review of the physics relating to the great system of which our earth is only a very inconsiderable speck, we find that although men of the highest scientific merit hard tried to explain the origin and nature of the Cosmos, and the laws by which it is governed, not one speculation had been adopted at the time of the publication of the "Cyclopædia" of Chambers, as possessing all the necessary precision for the entire satisfaction of inductive reasoning.

It was only at the end of last century that Pierre Simon Laplace published bis two great works, "Exposition du Système du Monde" in 1796, and "La Mécanique céleste" in 1799. This cosmogony, usually called the "Nebular Hypothesis," has hitherto stood the test of inquiry nearly a whole century ; all the facts-and they are innumerable-tending invariably to testify at least to the great probability of its general correctness. In justice I ought here to mention that Immanuel Kant published in 1755 his cosmical theories in his work "Allgemeine Naturgeschichte und Theorie des Himmels," in which the great Königsberg philosopher came to the same conclusions afterwards so convincingly demonstrated by the French mathematician.
But when we leave the Cosmos and confine ourselves to our small planet, we find ourselves surrounded by such difficulties that we appear just as far now from a true conception of the constitution of the earth's interior as our predecessors were at the beginning of this century.

Numerous theories, based upon careful calculations, as to the thickness of the crust of the earth have been advanced. Some physicists give to our earth so thin a cru:t that it has been compared to the rind of an orange, the fruit inclosed in it representing the molten matter of the globe; others affirm that the crust is of much greater thickness, while there are some who maintain that our planet has cooled so thoroughly that it now forms a mass of rock of various density from the surface to the very centre. Other theories (or, better stated, hypotheses) giving to our globe a crust of more or less thickness, with a hard metallic nucleus in the centre, and matter in a high state of fusion filling the space between both, have been advocated by other scientific men, and mathematical proofs in support have not been wanting. However, objections apparently fatal to them all have been bronght forward at one time or another by physicists, astronomers, or geologists, according to their particular line of study, and we can therefore only wait patiently and follow attentively the careful researches continued in all civilised countrie;, applying at the same time every new discovery to the elucidation of a problem, the more tantalising as its solution has for many years appeared to be within our grasp.

The great hopes that the deep borings lately obtained in artesian wells, or careful temperature observations in deep mines, would supply us with some material for advancing this question, by offering important and reliable data of a uniform character, have not been fulfilled. It appears, on the contrary, from the deep borings at Sperenberg, in Germany, reaching nearly to 4200 feet, that the increase of heat exhibits a remarkable retardation of its rate the deeper we descend. And even if we take convection and conductivity of the rocks into account, there are scarcely two localities where the same ratio of increase in the temperature has been observed, in some that ratio being more than treble that of others. There may once have been a uniform cooling of the original crust of the earth, now almost entirely removed or remodelled, but there is no doubt that this difference in the increase of temperature depends now either upon local generation of heat by hydro-chemical action or mechanical agencies of enormous power still at work. Thus in localising the variable increase of temperature, the vera causo both for the crumpling and metamorphism of rocks, for the formation of mountain chains, as well as for the origin of volcanic action, might be traced with more reliance than to seek to establish a general law that most probably no longer existed when the strata acce:sible to our examination were formed.

Leaving the domini.on of theory and returning to the actual work of the geologi:t in the field, I need scarcely say that the task already accomplished has been truly gigantic. Patient research in the civilised countries of Europe, in the United States of North America, and mont of the Engiish colonies, as well as the work of travellers to almost every part of the globe-of the latter I wish only to allude to Baron von Richthofen's excellent late researches in China - have made us acquainted with such remarkable and iunumerable data that it is impossible for any man, however studious he may be, to gain more than an imperfect knowledge of the material already accumulated.

The relations of the plutonic, metamorphic, sedicnentary, and volcanic rocks to each other have been clearly defined, and most valuable facts have been brought together, from which the past history of our globe is being constructed, while the palæontologist has done his work equally well in classifying the wonderfully complex animal and vegetable life, always in harmony with the conditions of the earth's surface, gradually and during untold ages reaching, by evolution, the present stage of existence and perfection.

It would lead me too far to enter into a discussion of all the theories advanced as to the cause or causes by which mountain chains and seas have been formed, and volcanoes and earth. quakes-because in most instances the two latter are intimately connected with each other-have been originated. Elie de Beaumont's theory of the sudden upheaval of parallel mountain chains, first published in 1833 , although at one time finding great favour on the continent of Europe, was never adopted by any geologist of note, the teachings of Hutton and Lyell leaving no room for the doctrines of the paroxysmal school. Moreover, when the size and direction of mountain chains were taken into 
account, and the roclis composing them were carefully examined, it was found that the explanations offered by the eminent French geologist could not be adopted.

Many valuable publications have been issued upon these subjects, of which those of Robert Mallet may in many respects claim our greatest attention. Another work of great value is that of Prof. E. Suess, the eminent Professor of Geology in the University of Vienna, "Die Entstehung der Alpen," the forma. tion of the Alps, in which this difficult question is treated in a masterly manner. Prof. Green's "Physical Geology" contains also an exhaustive részzmé of the physics of the earth's crust, in which all the newest researches and theories are thoroughly examined and sifted by an excellent observer and practical geologist. However, there is another distinguished geologist and physicist, Constant Prevost, whom I should not omit to mention, he having already explained, in 1822 , the elevation of mountain chains by tangential and lateral pressure, now mostly adopted as the correct theory. The deep-sea dredgings have also offered us considerable material to elucidate the former history of our globe, both from a stratigraphical and palæontological point of view.

The oscillation of land and sea is another subject of great im portance that has hardly received that attention it deserves, whether we take the so-called glacial period into account or not. There may be with many geologists the fear of appearing heterodox if they state their belief that the hydrosphere is, like the lithosphere, subjected to considerable oscillations, by which great changes in the climate of the globe may have been brough about in past geological ages. For years I have held and stated this opinion.

However, I find that lately a great deal of attention has been paid to this subject. Thus, for instance, $\mathrm{Ph}$. Fischer, Heinrich Bruns, and others, in discussing pendulum observations, have come to the conclusion that the sea-level is not a regular spheroid, but may vary many hundreds of feet even along the same parallel of latitude. Dr. Penck will also explain raised beaches and other siuns of the glacial period by the oscillation of the sea-level. Penck's views in this respect are different from those of Adhemar and Croll.

A nother factor for explaining great changes on the earth's surface, brought about in geological periods long past, has lately been put forward under the name of Tidal Evolution, a very ingenious theory, first worked out in its entirety by G. H. Darwin. It is based upon the action of the moon, once a part of our planet, on the earth, preducing the tides and retarding its motion, as well as upon the reaction of the earth upon its satel lite. Gradually the moon was driven away from our planet, and the length of day has thus at the same rate become more considerable.

However, when Prof. Robert Ball, in Dublin, and others attempt to make out that the former much larger tides, when the moon was closer to the earth, formed a powerful agent for the destruction of rocks existing at that time, and for the formation of newer beds from them, by which the thickness of the older sedimentary and fossiliferous strata can be explained, I think we have to pause before we can accept such a sequence.

Moreover, according to Sir William Thomson, there has not been any great change in the ellipticity of the earth's figure since its consolidation, consequently Mr. Darwin's views as to higher tides have to be modified, as he presupposes a more considerable ellipicity for his calculations. However, even assuming Prof. Ball's calculation, that when the moon was only 40,000 miles distant from the earth the tides at that time would rise and fall between 600 and 700 feet twice in twenty-four hours, to be correct, I have no doubt that it was long before the Cambrian or lowest fossiliferous rocks with which we are acquainted were deposited. The occurrence of numerous fossils in the oldest beds, belonging to animais that could live only in clear water, and minute ripple marks on the rocks, speak clearly against Prof. Ball's hypothesis.

This speculation in physical geography has already been tested by various geologists to account for the so.called marine denudation. This expression was first introduced by Sir Andrew Ram for the higher portions of ridges over large areas, that, if laid down on an imaginary plane, appear to have once formed one surface with a very gradual slope in one direction.

However, this peculiar appearance can, as I have repeatedly suggested in former publications, be easily explained by the fact that $\mathrm{w}$ hen the land gradually rose above the sea-level, abrasion on a gigantic scale must have taken place, by which, in the case of our Southern Alps, the whole had the appearance of a shallow dome, of which the western side was much steeper than the eastern, till the subaërial erosion by atmospheric agencies, or, as I called it, ridge-making, took place.

Before leaving this subject, to which I have devoted more time than perhaps I ought to have done, I may add that many speculations have been built upon it. Thus, Mr. O. Fisher attempts to prove that the ocean basin represents the scar whence the mass forming the moon separated from the earth.

Another cause of gradual retardation in the rotation of our planet, and to whicb, as far as I am aware, very little attention has hitherto been paid, is the increase of the bulk of our planet by meteorites and cosmic dust.

There is not the least doubt in my mind that matter, even in the most diffused state, cannot leave the outermost or gaseous portion of our planet, but that an enormous amount of matter in the form of meteorites must have been accumulated year by year. If we ac'd to this the cosmic duit falling upon the surface of the earth, whicb, according to a calculation by Nordenskjöld, may amount to haif a million tons yearly, the size of our planet must have been gaining in dimensions and weight to an almost inconceivable degree, even since a rich and diversified flora and fauna inhabited it. But even assuming that Nordenskjöld's estimate is far too high, and reducing it to a tenth, or to 50,000 tons yearly, the result of any calculation upon this basis is most astounding. Thus, if we take only a period of twenty millions of years, a short interval in the life-history of our planet, the co:mic dust falling during that time would add not less than $1,0,0,000,000,000$ or one billion of tons.

And this result is obtained without accounting in any way for the further addition by the fall of meteorites, without doubt of very considerable magnitude. Such a factor, as Prof. von Nordenskjöld forcibly points out in his last work, ought certainly not to be overlooked if we wish to account for various changes in the form, position, and rate of rotation of our planet since it began to consolidate.

I am well aware that several scientific men, who have carefully examined some of the cosmic dust, have come to the conclusion that it is in most cases of terrestrial origin; but the fact remains that some of the dust collected shows its cosmic origin by its constituent parts, and that all the meteorites reach us from far beyond the atmosphere of our earth.

The importance of the great doctrine of evolution as first fully established by Darwin cannot be overestimated by the palæontologist. Applying the leading facts of the origin and distribution of animal and vegetable life, as at present existing, to the numberless past generations preserved in the marvellous stone-book of Nature, he is able to unravel more fully their history, to account for the missing leaves, and to estimate at their just value those few remaining, and of wbich he now and then is privileged to decipher a small portion. Darwin himself, in his elassical chapter "On the imperfection of the geological record," in his "Origin of Species," has pointed out to us in his usual masterly manner how to avail ourselves of the scant material at our command, and how future discoveries, adding to the palæontological stock, will open out new vistas in the past history of our globe.

I need scarcely add that every nen addition to our knowledge will assist us to gain more fully day by day an insight into the harmonious unity of the whole.

It is not yet a quarter of a century (1859) since the "Origin of Species" appeared, but if we compare our knowledge of palæontology at that time with that obtained at present, we find that striking progress has been made. Instead of a collection of facts, more or less loosely connected, we now possess a system of remarkable strength and harmony, a powerful aid to an inductive science like geology.

Evolution might be compared to an architect, who succeeds in raising an edifice of pure and noble proportion;, placed upon a stable and firm fourdation, from a laroe accumulated material of finely and ingeniously wrought building stones stored up promiscuously without any apparent plan cr order.

Since the appearance of the "Origin of Species" I have always held this opinion; and I may be allowed to mention that as far back as 1862, in my opening address as first president of the Philosophical Institute, I spoke of this incomparable book as "the great work of the age."

The researches of the palæontologist have shown already convincingly that there are innumerable intermediate links 
between present species and those which lived in past ages. I may here, to give only one instance, refer to Huxley's important researches into the relations of the members of the family Equidæ, the Anchitherium, Hipparion, and Equus. At the same time the gulf between the different classes of vertebratez is being gradually bridged over by car ful research. Thus Prof. O. C. Marsh has shown that the jurassic bird Archzooteryx from Solenhofen is closely connected with the Dinosaurs, generally considered to be most nearly allied to birds. Archæopteryx has besides true teeth in sockets, bi concave vertebræ, the pelvic bones are separate, and the metatarsals either separate or at least imperfectly united. American fossil birds, such as Ichthyornis, have also bi concave vertebræ (like fishes and some Saurians), and teeth in sockets. The skull of Otontopteryx toliapicus, found in the Isle of Sheppey, in the London Clay, has also true teeth in sockets.

There is, however, in palæobotany still a great deal that is in many respects unsatisfactory and inconclusive. This is mainly owing to the fragmentary material at our command, consisting mostly of leaves, the determination of which in many instances may lead us to wrong inferences. To give only one instance, I wish to refer to O. Feistmantel's latest researches on the palæozoic and mesozoic flora of Australia, with which our own fossil flora is closely connected.

The eminent palæontologist of the Indian Geological Survey comes to the conclusion that Phyllotheca, in Europe and Siberia of jurassic age, is palæozoic in New South Wales, and upper mesozoic in Victoria; Glo sopteris, palæozoic in Australia, is jurassic in India and Rusia. Noeggerathiopsis, beginning to appear in palæozoic beds in Australia, is represented by the iuras: ic Rhiptozamites in Siberia.

It is unquestionable that such conclusions, before they can be adopted, have to be confirmed by evidence of a still more reliable character than the present material for comparison can have afforded.

Returning to the physical conditions under which the surface of our globe has been formed and i; still forming, I may here point out that since evolution has been adopted by most scientific men as a beacon to guide them to truth, the greater portion of the so-called uniformitarian school of geologists, following in the footsteps of Lyell, has become somewhat modified in its views, and may now be called the evolutional school. But let me hasten to add that I.yell himself, with his great love for truth, may be claimed as one of its first disciples, he having review'ed his own writings by the light Darwin held up to us, which is sure to advance geology even more than we can at present realise.

There is one question of great importance, in the solving of which buth the geologist and the palæontologist have to go hand in hand with the archæologist. There is no doubt that the human race existed already in pliocene times; and if we can trust the reports of discoveries in Portugal and other pcrtions of Southern Eutope, man may have lived as early as the miocene age.

However, we want further and clearer evidence before this latter view can be adopted. If we concider the enormous space of time that separates us from our first ancesto:s, the oldest historical facts preserved seem to us as of to-day; and taking into account the wonderful progress the human race has made from the condition of the cave-dwellers, with their rude stone implements, to our present state of civilisation, we ought to look roudly upon the position mankind has attained. And we can therefore scarcely conceive the high degree of perfection, both physically and mentally, the human race may reach is future.

Although, as far as our researches go, the autochthones of New Zealand cannot boast of great antiquity when compared with the inhabitants of the Northern Hemispleere or of the tropical regions, there is nevertheless strong reason to believe that this country has been inhabited for a much longer time than was formerly generally assumed.

It is, however, possible, that some of the traces we have hitherto found of the oldest occupancy of the:e islands may have been left behind by occasional visitors, adventurers in search of new countries, or by crews of wreclied ships coming from distant shores.

But we have only begun to examine these questions; and although, as is always the case, the wiseacre.; will first shake their heads, if our researches are only continued without fear and without preconceived conclusions, we may be certain that aluable results will be in store for us.
The existence of loess beds, often of considerable thickness, in numerous parts of New Zealand, of which many have begun to be deposited before the beginning of our great glacier period, will be of great use, and offer us an excellent field for research in this direction. These beds being of subaërial origin, not only the remains of land animals are preserved in them, but we shall find in them also the traces of man. I may here mention the strange fact that the true nature of these beds has for a long time been misunderstosd and misinterpreted by most English geolo. gists. Even in the last edition of Lyell's "Elements of Geology," the loess cf the Rhine is described as fuviatile loam, whilst the autbor himself shows that only the remains of land shells and land vertebrates are embedded in it. It has always been inconceivable to me how such an error should have re mained so long uncorrected ; the more so as, as far back as 1847 , Alex. Braun, in "Leonhard and Bronn's Nenes Jahrbuch," has shown the true state of things, and German geolugists have repeatedly furnished new facts in illustration and given analyse: of loess and of recent and older fluviatile deposits of the Rhine for comparison.

But, as I have previously pointed out, the peculiar nature of the loess deposits-the minute vertical capillary structure caused by the empty spaces once filled by the rootlets of innumerable generations of grasses-is a sure guide even to a tyro in geology. This structure amongst these localities is well exhibited in the fresh cuttings near Lyttelton.

I fear that the time allotted to me will not allow me to enter more fully into a review of what has already been accomplished to make geology an inductive science, and what remains still to be done, but I may be permited to allude to one of the principal causes that retarded geology from taking its present position. Thi; was the fear of the student to enter into antagonism with the established religious cosmogony. It is unnecessary to allude to the middle ages, because the stake or disappearance in the dungeons of the holy inquicition were the rewards of fearless physical research, and men like Galileo and Descartes were obliged to use often evasive language, unworthy of such great thinkers, in order to reserve their lives or freedom, and therefore my remarks will only apply to our own times. In proof of this I wish only to guote one work, "Vestiges of the Natural History of Creation," of which the first edition a; peared in 1844. If we read this book at the present time, we can scarcely understand how it could have created such intense indignation amongst a large portion of the community, or that so much could have been written against it. Lyell himself, when pub lishing his "Principles of Geology," a work of a true philosopher, wac, judying from scme letters in his biography, very careful not to hurt too much the prejudices of his time, not wishing to mar the usefulness of his work. Even at the present time are there not thou ands and thousands of will-meaning but narrow-minded persons, at once entering int, strenuous opposition when there is any reference made to scientific cosmogony differing from that they have been accuitomed to from their youth, and that cannot stard before the light of modern research?

However, the great principle of liberty for the teacher, so well expressed by the (ierman word "Lehrfreiheit," cherished by the whole Teutonic race, a principle even preserved in the German universities during the darkest days of absolutism, is a safeguard of inestimable value, possessed furtunately also by our New Zealand University, the Alma Mater for $x$ hose advancement to the highest atrainable position and general utility we ought willingly to devote our whole strength and best energies.

\section{DUST-FREE SPACES 1}

WITHIN the last few years a singular interest has arisen in the subject of dust, smoke, and fog, and several scientific researches into the nature and properties of these phenomena have been recently conducted. It so happened that at the time I received a request from the Secretary of this Society to lecture here this afternoon I was in the middle of a research connected with dust, which I had been carrying on for some months in conjunction with Mr. I. W. Clark, Demonstrator of Physics in University College, I iverpool, and which had led us to some interesting results. It struck me that possibly some sort of account of this investigation might not be unacceptable to a learned body such as this, and accordingly I telegraphed off to

I Lecture to the Royal Dublin Society by Dr. Oliver J. Lodge, April 2. 